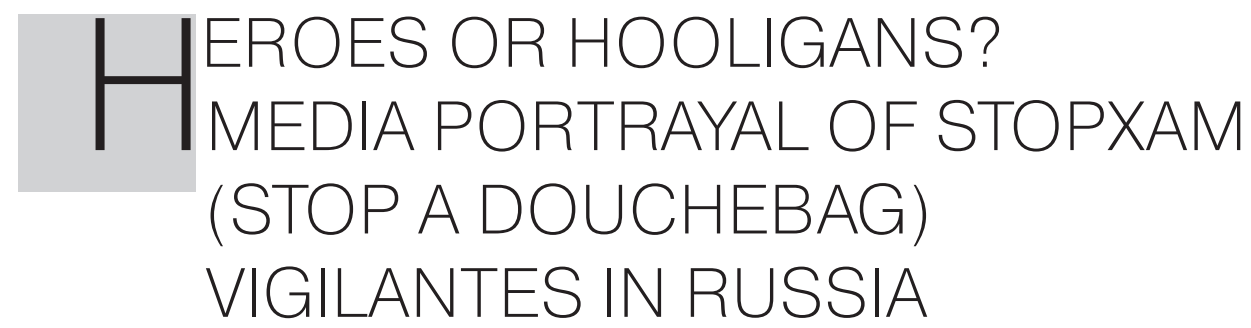

\title{
Rashid Gabdulhakov
}

Rashid Gabdulhakov, Department of Media and Communication, Erasmus University Rotterdam. Address for correspondence: Erasmus University Rotterdam, Postbus 1738, 3000 DR Rotterdam, Netherlands. gabdulhakov@eshcc.eur.nl.

The author expresses sincere gratitude to the informants for their contributions, as well as to peer reviewers and editors of this special issue for their valuable feedback. This work was supported by the Dutch Research Council (NWO) project number 276-45-004.

Several state-supported digital vigilante groups emerged in Russia at the downturn of the pro-Kremlin youth group Nashi (Ours), when its former commissars formed issuespecific movements to counter perceived legal and moral offences through exposure of targets on social media. One of such groups is StopXam (Stop a Douchebag), specializing in road-traffic and parking violations. StopXam participants confront the drivers and retaliate by placing stickers that read "I spit on everyone I drive where I want" on the targets' windshields. The retaliation is often accompanied by verbal and physical fighting; the process is filmed, edited, and shared on YouTube, receiving millions of views. While digital media made such practices possible, traditional broadcasters maintain significance in rendering meaning to the phenomenon of vigilantism and in framing vigilantes, their targets, police, and other actors. As the existing literature on digital vigilantism is predominantly focused on digital media affordances, this article aims to address this gap through a qualitative analysis of traditional media coverage of StopXam. Media analysis highlights intriguing nuances of traditional media as a powerful actor and discourse setter in the digital age.

Keywords: StopXam; Digital Vigilantism; Citizen-Led Justice; Russia; Traditional Media; Qualitative Content Analysis; Framing

Several state-endorsed vigilante groups sprawled across Russia in the wake of the dissolution of the Kremlin's Nashi (Ours) youth movement in 2010 (for more on Nashi, see Atwal and Bacon 2012; Hemment 2012; Mijnssen 2014). One of the most successful projects to come out of Nashi is the StopXam ${ }^{1}$ (Stop a Douchebag) movement against

1 Pronounced "StopKham." While transliteration of the title varies between "StopHam," "StopXam," and "StopKham," this article relies on the spelling "StopXam" and the translation "Stop a douchebag" as used by the group itself across its social networking profiles. 
rudeness on the roads. With branches across Russia's major cities and abroad, ${ }^{2}$ StopXam specializes in the pressing issue of road-traffic and parking violations. Vigilantes use digital media to frame, expose, shame, humiliate, and otherwise punish their targets. Retaliation is achieved through embodied harms and "weaponisation of visibility" (Trottier 2017). StopXam participants confront the drivers and retaliate by placing stickers that read "I spit on everyone I drive where I want"3 on the targets' windshields. The retaliation is filmed, edited, and shared on StopXam's YouTube channels, receiving millions of views. As such, the audience plays a key role in digital vigilantism, as exposure is used in punitive terms and each new view, "like," comment, and repost can intensify the impact of harms. While digital media made such practices possible, traditional media remains a significant player in rendering meaning to digital vigilantism and in the framing of participants, their targets, police, and other actors (Gabdulhakov 2019:233). The audience is informed both by vigilantes through their media products and by traditional media outlets reporting on cases. Thus, traditional media coverage not only has the capacity to impact the perception of digitally mediated social justice by the public, but also has the power to frame the very notion of justice amid social frustrations and biases-gender, ethnic, socioeconomic, political, and other-that come to surface with each case. Beyond this, traditional media reports can afford popularity to vigilantes while harming the targets through additional exposure.

As conceptualized by Les Johnston (1996), vigilantism implies autonomy of participants from the state. For Johnston, autonomy is key to understanding vigilantism as it sets the practice apart from other forms of "responsible citizenship" that can be "sanctioned and sponsored by the state" (1996:226). Digital vigilantes are not entirely autonomous but are asserting "new boundaries" (Trottier 2017:59) for establishing and negotiating relations with the state. In Russia, certain participants such as StopXam have been endorsed and supported by the government. Leaders of vigilante groups not only have taken selfies with key state leaders, including Dmitrii Medvedev (Russian president in 2008-2012 and prime minister since 2012) and Vladimir Putin (president in 2000-2008 and again since 2012 and prime minister in 2008-2012), but also have received state financial support for their activities (Gabdulhakov 2018). In this regard, in Russia vigilantism is not taking place as a response to the absence of state authority, but is approved by that authority, taking on an institutionalized form such that participants resemble government-organized nongovernmental organizations.

As the existing literature on the phenomenon of digital vigilantism is predominantly focused on digital media (Cheong and Gong 2010; Kasra 2017; Smallridge, Wagner, and Crowl 2016; Stratton, Powell, and Cameron 2017), the assessment of traditional media's role and power often remains outside of scholarly attention. Traditional media demonstrates a continual "influence in social media environments" (Meraz 2016:66), yet the current literature lacks empirical studies addressing the complex dynamics of relations between traditional media, digital vigilantes, and

\footnotetext{
2 In Armenia, Belarus, Georgia, Moldova, Ukraine, and Peru.

${ }^{3}$ The group's own ranslation from Russian (https://stopadouchebag.org/).
} 
state/corporate actors, especially in a context where the ruling elite both controls the media and endorses vigilantism. In order to fill this scholarly gap and to investigate these boundaries, this article provides a detailed account of media framing of Russia's most prominent vigilante group-StopXam. Guided by the methodological works of David Altheide and Christopher Schneider (2013) and Helene Starks and Susan Brown Trinidad (2007), the study carried out qualitative content analysis of Russia's four prominent state-controlled channels-Pervyi kanal (Channel One), NTV, REN TV, Rossiia 24-and a nonstate broadcaster, Telekanal Dozhd' (also known as TV Rain). Furthermore, the study is informed by interviews with StopXam participants. By looking at the coverage period between 2010 and 2018, the article illustrates the uneven framing of StopXam as a group that was endorsed by the country's leadership, shut down by court decision in 2016, rehabilitated six months later, and liquidated again in 2018.

This study makes a timely contribution to the literature surrounding digital vigilantism and aims to expand theoretical frames of definitional dimensions of vigilantism by addressing the role of audience and traditional media in the digitally mediated manifestation of this phenomenon. The article aims to do so by addressing the following questions: How are StopXam participants, their targets, and police forces portrayed in Russia's traditional media? What is the role of traditional media in rendering digital vigilantism meaningful?

I will first introduce StopXam as a movement and elaborate on the existing conceptual frameworks to address the phenomenon of digitally mediated social justice. I then provide a brief background on Russia's traditional media and the selected platforms, followed by a detailed account of StopXam's portrayal by these broadcasters. I conclude that traditional media is a powerful actor and discourse setter that can justify and condemn targets, police, and participants in spite of the vast digital media capacities of the latter.

\section{STOPXAM: BACKGROUND}

One of the key figures behind StopXam is a former Nashi Commissar, Dmitrii Chugunov. According to his official biography listed on the website of Russia's Civic Chamber, ${ }^{4}$ of which he was a member between 2014 and 2017, Chugunov served in Russia's special police units_-Vitiaz' and Taifun-in 2006-2008 and was deployed to Dagestan in 2007 as a sniper. Chugunov is the champion of the Eastern Regional Command of the Internal Troops of the Ministry of Internal Affairs in judo, sambo, ${ }^{5}$ and rifle firing. As the leader of StopXam, Chugunov reported on its successes to Pu-

4 The Civic Chamber was established in 2005 under the Federal Law On the Civic Chamber of the Russian Federation. The Civic Chamber comprises prominent citizens of Russia, representatives of national, regional, and interregional NGOs (https://www.oprf.ru/en/about/). Chugunov's biography in Russian is available here: https://www.oprf.ru/ru/chambermembers/members/ user/1681? year=2014.

5 Sambo is a form of marshal arts and combat sport developed in the Soviet Union; the word "sambo" stands for "self-defence without weapons" in Russian. 
tin during personal meetings in 2011 and 2012. In response, Putin expressed his positive views of the movement:

You are doing a very important and good deed-fighting rudeness. Behavior on the road is part of a person, and I very much count on the fact that you yourself, while doing your work, will be on top, and will not be like those people who behave ugly towards others. (NTV 2013)

The signature retaliatory act of StopXam (the group itself and media reports refer to activities as "raids") is a sticker placed on the target's windshield. The raids are often accompanied by verbal and physical confrontations between participants and the drivers. Targets' appearance in the edited videos subjects them to further shaming and exposes them in a manner that can harm reputation. As Daniel Trottier puts it:

The visibility produced through DV [digital vigilantism] is unwanted (the target is typically not soliciting publicity), intense (content like blog posts, photos and video evidence can circulate to hundreds of thousands or even millions of users within a few days) and enduring (the vigilantism campaign may be the first item to appear when searching the individual's name, and may become a cultural reference in its own right). (2017:56)

Indeed, several targets of the group, including high-profile state functionaries and their relatives, have lost their jobs following the exposure on YouTube and in traditional media reports. Among the biggest cases are the dismissal of Chechnya's deputy presidential plenipotentiary in Moscow, whose wife had a clash with StopXam, and the resignation of the head of Moscow's Mar'ino district, who appeared in a video where his wife was confronted by the group ("Dos'e: StopXam" n.d.). Such negative publicity of high-profile targets fuels the legitimization, popularity, and power of StopXam participants. In a 2012 interview, StopXam's former spokesperson Oksana Mitrofanova was asked if she could identify the moment that popularity came to the group. Mitrofanova came up with two cases: "when the owner of a Maybach [a German luxury car] was hit in the face" and the confrontation with the wife of the Chechnya's deputy presidential plenipotentiary in Moscow. In the same interview Mitrofanova stressed the importance of visibility as a disciplinary tool, explaining that "those violating orders understand in their head that their actions can end up on YouTube" (Smimimi Russia 2012).

When traditional media relies on "evidence" submitted by StopXam activists and provides links to their social media channels, it turns into a mediator of retaliation, linking "conventional" viewers to online content. Traditional media platforms increasingly use digital media for dissemination of their content, thus blurring the lines between offline and online news delivery. At the same time, vigilantes' media products can enjoy an extra layer of legitimation by virtue of being featured in official media. By reporting on vigilantism in a manner that justifies such practices, traditional media can set "a fashionable trend for young people" (A. P. 2018), poten- 
tially inspiring new participants across and beyond Russia. As one former member of StopXam in Moldova explained:

We were thinking about starting our own initiative to fight against bad parking. However, Russia's StopXam was already well known and we decided to collaborate with them and open a branch of StopXam as opposed to starting from scratch. (Interview with a participant from Moldova)

A global network of affiliated movements further boosts the significance, popularity, and recognition of the brand; on their YouTube channel, Chugunov dedicated a special episode to presenting steps for establishing a local StopXam branch. In the video Chugunov states that StopXam treats branches "very seriously" as "branches contribute to the impression of the movement as a whole" (StopXam 2017). Chugunov suggests that viewers film a short video about themselves and their team and send it to the provided email. Approved branches are promised help with "all possible resources," namely "expert advice, legal help, StopXam media resources, and help with the journalists" (StopXam 2017). The last point underscores the importance of establishing relations with traditional media for a successful operation of a digital vigilante group.

As of 2016, StopXam is represented in Peru under the name Mal Estacionado (Badly Parked), which is a rare case of operation outside of the post-Soviet bloc. Mal Estacionado was inspired by StopXam and is endorsed by the original Moscow-based group:

I was watching YouTube one day and saw Stop a Douchebag videos. I thought, "wow, we need something like this here." A friend helped me with the stickers and we made some videos. I was afraid they [original StopXam in Russia] would not like it that I copy them. I contacted them and sent my videos and they said "go ahead, keep doing it." They featured us on their channel. (Interview with a participant from Peru)

The group was featured on StopXam's YouTube channel on December 30, 2018, as a "Peruvian branch" (StopXam 2018). As of June 2019, it is a small-scale operation, with six participants in Lima who hope to grow into something bigger:

It is hard to recruit people, they say "yes, I will come, you are doing a great job, I want to join" and then they never show up. I think the Russian movement is much larger, they have so many people. We are operating only in Lima and it is just six of us, while two people deal with cameras, so really, just four people. (Interview with a participant from Peru)

Members in Lima mentioned that besides their activism they hold full-time jobs and participation is a "side project." During the conversation, they expressed satisfaction with the traditional media coverage of their activities in the country. Upon the advice of StopXam Moscow, Lima participants adopted the practice of placing English-language subtitles in their videos to engage a wider global audience. As of 
June 2019, Mal Estacionado's YouTube channel featured 16 videos, 10 thousand subscribers, and 1.7 million total video views.

The original Moscow-based movement runs two YouTube channels, in Russian and English languages. Videos are uploaded on average once a week, with total views numbering in the hundreds of millions. As of June 2019, StopXam's official Russianlanguage YouTube channel featured 216 videos; the channel had 1,631,464 subscribers and 426,635,221 total video views (StopXam n.d.a). The English-language channel, Stop a Douchebag, featured 200 videos with 781,000 subscribers and 224,618,484 total video views (Stop a Douchebag n.d.). The vast following and popularity of StopXam affords unique powers to participants, allowing them to widely expose their targets, monetize YouTube videos, sell merchandise, and acquire other forms of capital, including social recognition and status. ${ }^{6}$

In addition to these media capacities, StopXam has enjoyed the endorsement of the highest authorities in Russia. In 2017 President Putin called on the Ministry of Internal Affairs to collaborate with citizen activists, thus legitimizing movements such as StopXam and ensuring police protection over them (Gabdulhakov 2018). As Chugunov has put it, through public endorsement, Putin essentially gave the project his own "blessing" (Suzdaltsev 2015). Registered as an NGO, StopXam received presidential grants in support of its activities. Media reports estimate these grants in the amount of 21,000,000 rubles (NTV 2016c). ${ }^{7}$ Court decisions to liquidate StopXam as a legal entity in 2016 and 2018 made the group ineligible for state grants.

\section{CONCEPTUALIZING STOPXAM AS A VIGILANTE FORCE}

Although vigilantism as a social scientific category of citizen-led policing and social justice is rooted in nineteenth century practices in the USA, digital vigilantism emerged as a global phenomenon amid the visibility and wide participation capabilities afforded by digital media in recent decades.

The conceptualization of vigilantism was initially developed by $\mathrm{H}$. Jon Rosenbaum and Peter Sederberg in the 1970s. In their take on the phenomenon Rosenbaum and Sederberg proposed that: "When individuals or groups identifying with the established order defend that order by resorting to means that violate these formal boundaries, they can be usefully classified as vigilantes" (1974:542). After a lengthy pause in scholarly attention to the phenomenon, Johnston took on the task of conceptualizing vigilantism by narrowing key definitions; for Johnston (1996:232),

vigilantism is a social movement giving rise to premeditated acts of force-or threatened force-by autonomous citizens. It arises as a reaction to the transgression of institutionalized norms by individuals or groups-or to their potential or imputed transgression. Such acts are focused upon crime control and/or social control and aim to offer assurances (or "guarantees") of security both to participants and to other members of a given established order.

\footnotetext{
${ }^{6}$ For instance, membership in the Civic Chamber.

7 On the day of the NTV report release (June 21, 2016) this amounted to roughly 326,527 USD.
} 
In his definition, Johnston proposed six "necessary features" of vigilantism: (1) planning and premeditation; (2) private and voluntary participation; (3) autonomous citizenship constituting a social movement; (4) use or threat of use of force; (5) vigilantism "arises when an established order is under threat from the transgression, the potential transgression, or the imputed transgression of institutionalized norms"; (6) vigilantism "aims to control crime or other social infractions by offering assurances (or 'guarantees') of security both to participants and to others" (1996:220).

The quest for definitional conceptualization of vigilantism was further carried by Daniel Trottier $(2017,2019)$ and Eduardo Moncada $(2017)$. Trottier proposes a focus on digital media affordances for vigilante practices and defines digital vigilantism as "a process where citizens are collectively offended by other citizen activity, and coordinate retaliation on mobile devices and social platforms" (2017:56). In the same article Trottier compares Johnston's six necessary features of conventional vigilantism with its digital manifestation, suggesting a layer of spontaneity to planning; possible links between vigilantes and state/corporate actors; new boundaries in "autonomous citizenship"; weaponized visibility in addition to embodied use of force; a "fusion of local and mediated norms" (59) in reaction to crime; and "mediated" as opposed to localized policing in attempted provision of personal and collective security.

Moncada defines vigilantism as "the collective use or threat of extralegal violence in response to an alleged criminal act" (2017:408). He proposes five core definitional dimensions for the conceptualization of vigilantism, namely: (1) social organization: social ties shaping the "coordination and execution of vigilantism"; (2) targets: individuals who violate orders and thus commit formal (breaking the law) or informal (perceived) offences; (3) repertoire: lethal (for instance, hanging) and nonlethal (bodily harms, psychological torture) practices that vigilantes utilize to make their claims; (4) justification: legitimization of vigilante behavior in the public eye through claiming to act on behalf of the community; (5) motivation: reasons for participation in vigilantism (407-408).

When applied to StopXam, Moncada's definitional dimensions fit in a rather straightforward manner, as the group is a collective with identified targets-roadtraffic and parking violators (formal offence); participants retaliate through the nonlethal repertoire of shameful stickers, as well as verbal and physical confrontation with the drivers, which is filmed and uploaded to YouTube, leading to reputation damage and other undesired consequences (such as job loss) for the targets; they justify their acts by framing the police as dysfunctional and explain their motives as a genuine struggle against "traffic rule violations and arrogance on the road" (Stop a Douchebag n.d.). However, beyond the conceptual fit, there is a significant amount of nuance accompanying each dimension. Table 1 illustrates the application of Moncada's definitional dimensions to the case of StopXam. Building upon Trottier's visibility weaponization, I propose a sixth dimension crucial to digital vigilante practices-the audience. 
Table 1. Eduardo Moncada's definitional dimensions of vigilantism and the StopXam case

\begin{tabular}{|c|c|c|}
\hline \begin{tabular}{|l|} 
Moncada's \\
definitional \\
dimension
\end{tabular} & StopXam & Nuances \\
\hline $\begin{array}{l}\text { Social } \\
\text { organization }\end{array}$ & $\begin{array}{l}\text { Initially endorsed by the state. New } \\
\text { branches across and beyond Russia } \\
\text { are approved by the original founders } \\
\text { in Moscow. }\end{array}$ & $\begin{array}{l}\text { Brand-like position of the original } \\
\text { group allows for (dis)approval of } \\
\text { similar formations across Russia and } \\
\text { beyond its boundaries. }\end{array}$ \\
\hline Targets & $\begin{array}{l}\text { Targets violate formal orders-park- } \\
\text { ing and driving on sidewalks. At } \\
\text { times, informal violations enter the } \\
\text { scene during the confrontation, } \\
\text { as participants attack the target's } \\
\text { speech, appearance, ethnic back- } \\
\text { ground, social status, and other ac- } \\
\text { tions and identity markers. }\end{array}$ & $\begin{array}{l}\text { Among StopXam's targets are ordinary } \\
\text { and famous people (and their rela- } \\
\text { tives). StopXam has also targeted the } \\
\text { police, who are depicted as dysfunc- } \\
\text { tional. Targeting the elite socioeco- } \\
\text { nomic caste driving expensive cars } \\
\text { turns retaliation into a class struggle } \\
\text { and collective citizen-led justice/ } \\
\text { order restoration phenomenon. }\end{array}$ \\
\hline Repertoire & $\begin{array}{l}\text { The infamous sticker, verbal and } \\
\text { physical confrontations, exposure } \\
\text { through edited YouTube videos. }\end{array}$ & $\begin{array}{l}\text { Violence is a significant component } \\
\text { of StopXam's repertoire. Videos with } \\
\text { verbal and physical confrontation at- } \\
\text { tract wider audiences and make sen- } \\
\text { sational news pieces for traditional } \\
\text { media, bringing greater recognition } \\
\text { to participants and further undesired } \\
\text { exposure to the targets. } \\
\end{array}$ \\
\hline Justification & $\begin{array}{l}\text { Justification comes from underlining } \\
\text { the dysfunctionality of police forces } \\
\text { who are framed as indifferent at best } \\
\text { and corrupt and fearful of approach- } \\
\text { ing expensive cars at worst. }\end{array}$ & $\begin{array}{l}\text { In spite of accusations of dysfunc- } \\
\text { tionality and corruption, participants } \\
\text { turn to the police in certain cases. } \\
\text { The police can be called in to the } \\
\text { scene; video materials are evidently } \\
\text { sent by participants to the police } \\
\text { (StopXam n.d.c). }\end{array}$ \\
\hline Motivation & $\begin{array}{l}\text { Participants claim moral motives for } \\
\text { their activities, with the following } \\
\text { mission statement on their official } \\
\text { social networks: "We do not fight for } \\
\text { the law. We fight for people to think } \\
\text { about the rights and the convenience } \\
\text { of others regardless of whether there } \\
\text { is a police officer near them or not" } \\
\text { (StopXam n.d.b). } \\
\end{array}$ & $\begin{array}{l}\text { Beyond the genuine concern for } \\
\text { the situation on the roads, a set of } \\
\text { capitals and benefits is afforded by } \\
\text { participation, from YouTube content } \\
\text { monetization to receiving state } \\
\text { grants to building political careers } \\
\text { and acquiring other kinds of capital } \\
\text { through publicity. }\end{array}$ \\
\hline \multicolumn{3}{|l|}{$\begin{array}{l}\text { Proposed } \\
\text { definitional } \\
\text { dimension }\end{array}$} \\
\hline The audience & $\begin{array}{l}\text { StopXam enjoys a significant fol- } \\
\text { lowing on YouTube, with total video } \\
\text { views counting in the hundreds of } \\
\text { millions. A YouTube channel with a } \\
\text { massive following is a powerful tool } \\
\text { in the hands of vigilantes, which } \\
\text { grants them colossal comparative ad- } \\
\text { vantages in punitive exposure. With } \\
\text { branches across and beyond Russia, } \\
\text { context in featured videos is tailored } \\
\text { to local realities. StopXam, however, } \\
\text { is not limited to "the" channel; the } \\
\text { group is turning into a recognized } \\
\text { brand and a method. }\end{array}$ & $\begin{array}{l}\text { Digital vigilante groups such as } \\
\text { StopXam (among similar vigilante } \\
\text { formations in Russia are Khriushi } \\
\text { Protiv, Lev Protiv, and others) are } \\
\text { dependent on audience as visibility } \\
\text { amplifies harms experienced by } \\
\text { targets. Furthermore, successful } \\
\text { YouTube monetization requires a vast } \\
\text { audience. The audience can also sup- } \\
\text { port participants through donations } \\
\text { and merchandise purchase. }\end{array}$ \\
\hline
\end{tabular}


When retaliation is broadcast to mass audiences through the group's social media channels and through traditional media reports, visibility in itself becomes a weapon of vigilantes (Trottier 2017), affording the "longevity and recurrence" of exposure and intensifying the harms (Gabdulhakov 2019:231). The audience is, therefore, by default fundamental to amplification of harms experienced by the targets. Platforms such as YouTube, in this regard, serve unique roles as theaters for digital vigilantism and at times "tolerate or even cultivate such coordinated forms of social harm," given that the latter can be beneficial for the "business models" (Trottier 2019:13). In a way, StopXam's YouTube channel operates as a professional entertainment program and not as an extemporaneous amateur product. Participants often interrupt their videos with homemade ads for hedge funds, video games, and other products and services. Targeting famous people helps attract wider audiences, affording positive visibility for participants and generating income through YouTube monetization and advertising.

Here it is important to consider the role of the audience and the potential sympathy or condemnation projected on participants and targets. In 2016 NTV conducted a Twitter survey where the readers were asked to express their opinions on StopXam's legitimacy by answering the question "Is StopXam activism legal or not?" The results showed that $35 \%$ of 6,767 respondents view the group's activity as legal; another 35\% said "no"; and 30\% said "no, but I support them" (NTV 2016b). The image of StopXam participants as agents of social justice who work on behalf of the audience and in spite of police corruption/dysfunctionality (Favarel-Garrigues and Huérou 2004; Oleinik 2016; Wilson et al. 2008) is further supported by traditional media when participants are framed as public avengers, bringing the "road bores" to justice.

\section{TRADITIONAL MEDIA FRAMING}

Over the course of decades of empirical testing, the agenda-setting theory (McCombs and Shaw 1972) has been divided into three levels, where the first level "asserts that the public considers objects that are prioritized in the news as the most important"; the second level states that "properties or characteristics the news media use to portray a certain object will influence how the audience perceives that object"; and the third level, or the Network Agenda Setting Model, "asserts that the news not only tells us what to think and how to think, but also determines how we associate different messages to conceptualize social reality" (Guo 2016:3-4). The difference between agenda setting and framing, as argued by Craig Carroll (2016), is in the focus on explicit linkages (uniting objects, actors, and attributes as nodes) of the former and implicit linkages of the latter. As such, "salience for framing concerns intensity" while in agenda setting it concerns frequency (Carroll 2016:36).

Dennis Chong and James Druckman define framing as "the process by which people develop a particular conceptualization of an issue or reorient their thinking about an issue" (2007:104). Robert Entman takes the definition a step further suggesting that framing can be viewed as "the process of culling a few elements of per- 
ceived reality and assembling a narrative that highlights connections among them to promote a particular interpretation" (2007:164). Entman assigns an active element to framing by specific actors, beyond the passive development of a perception by the audience. In this case, when applied to StopXam in Russia, participants themselves can construct frames for self-promotion and mobilization of supporters and new members. In turn, traditional media has the power of spotlighting a variety of voices, including those of the state, police, targets, and counterforces. With the help of mass media, a group of participants can appear larger than it is, as viewers can develop a sense that activists are omnipresent.

\section{RUSSIA'S TRADITIONAL MEDIA}

Before elaborating on the nature of reports on StopXam, it is suitable to provide a basic overview of the state of Russia's traditional media and selected platforms. The current media landscape in Russia can be described as one controlled by "regimefriendly businesses" providing viewers "with an officially-approved version of what is happening in Russia and the world" (Orttung and Walker 2013:2). Stephen Hutchings and Johanna Szostek argue that controlling the circulation of media narratives at home and abroad is a matter of national security in Russia (2015:184). Being concerned with domestic narratives, this research focuses on broadcasters targeting domestic audiences. While some "alternative" sources of information are still available amid the intense media control in Russia, "critical voices have been increasingly stifled" (Hutchings and Szostek 2015:184). One example of such pressure is TV Rain. In this particular case, cable companies unplugged the broadcaster, forcing it to move into the online domain and rely on viewer donations to sustain operations (TV Rain n.d.b).

Sara Oates argues that any understanding of the Russian media landscape should be constructed around three fundamental points: (1) Russian media is diverse, but not on "key political topics"; (2) most media outlets do not challenge the state (especially on political topics); (3) media in Russia is consumed with enthusiasm (2016:402). Thus, it can be summed up that state-sponsored media outlets and Russia's ruling regime present a strategic dynamics where regime-loyal narratives are a default necessity; these narratives, in turn, are expected to support regime stability. Of course, the level of audience trust in consumed media comes into play. Levada Center reports that television remains the most popular source of news for $72 \%$ of Russia's population (Volkov and Goncharov 2019). In 2009 this number was at 94\%, which indicates a decline in television news consumption amid an increase in the consumption of news from online sources-a practice that saw an increase from $9 \%$ to $30 \%$ between 2009 and 2019. Viewers' trust in television as a source of news also experienced a decline from $80 \%$ in 2009 to $55 \%$ in 2019 (Volkov and Goncharov 2019).

State-controlled media in Russia underwent several waves of restructuring and, as Vera Tolz and Yuri Teper argue, these "major changes" in approaches to coverage can no longer be viewed from the standpoint of "neo-Soviet" or "neoauthoritarian" models; rather, there is an increase in political and "ideological messaging," which at the same time allows the broadcasters to maintain their position as "the chief pro- 
ducers of agitainment content" (2018:11-12). Tolz and Teper define "agitainment" as "controlled media output, alongside its systematic employment of specific global media formats to enhance its impact on viewers" (2). Thus, controlled state broadcasters in Russia appear to take on the roles of norm setters and official discourse articulators, while entertaining the audience.

\section{DATA COLLECTION}

This research draws its sample from the country's top broadcasters with news programs: Channel One, NTV, REN TV, and Rossiia 24. In addition to these state broadcasters, the study features a nonstate platform representing the scant independent media in the country-TV Rain. Selected broadcasters maintain websites with archived news blocks in the form of videos and transcribed text, serving as artifacts for the purposes of the current research. In the selected time period keywords вигилантизм/виджилантизм (vigilantism) and вигилант (vigilante) bore no results. ${ }^{8}$ News reports were sought by typing in keywords, namely variations of spellings of the group's name in the Cyrillic alphabet: СтопХам, Стоп Хам, стопхам, стоп хам. Select results that featured unrelated topics due to algorithmic errors were removed. A total of 307 news pieces were analyzed in this study: 4 from Channel One, 48 from NTV, 149 from REN TV, 98 from Rossiia 24, and 8 from TV Rain.

Data in the form of screenshots was collected directly from the archives available on the broadcasters' websites. The broadcasters were chosen with the aim of featuring the most prominent, regime-loyal platforms representing the voice of the state, as well as a nonstate voice represented by TV Rain. While the collected data is public, I refrain from directly revealing the names of targets in the text, so as not to confer any additional undesired publicity.

The data was collected with the awareness of limitations as online archives are not guaranteed to be fully comprehensive due to the fact that broadcasters may not necessarily archive the entirety of their news products while some digitally archived content is vulnerable to disappearance, as broadcasters tend to remove certain sensitive pieces from their otherwise open-access archives (Moscow Times 2019). In spite of these limitations, 307 news pieces representing each year in the selected coverage period between January 1,2010, and December 31, 2018, were gathered. The period was selected to comprehensively address media coverage since StopXam's formation in 2010 until initial liquidation in 2016, subsequent rehabilitation by the Supreme Court, and the most recent liquidation in 2018. All the data in the form of screenshots was stored in the secure digital vault provided by the author's institution. The study utilized specialized software, Atlas.ti, to organize, code, and analyze the data. Data analysis involved a detailed study of every news piece for identification of recurring themes in the portrayal of actors involved: participants, targets, police, and so on. Per Altheide and Schneider (2013), the report-production phase of the article involved summarizing each of the categories in short paragraphs, using

${ }^{8}$ Only in 2019 was the term "vigilantes" used to address StopXam by Russia's parliament member Viktor Zubarev, as he was quoted across traditional media (Sokolov 2019). 
illustrative materials where appropriate, including descriptions and quotations. A detailed description of the protocol is available in Appendix.

\section{SELECTED BROADCASTERS}

With $98.8 \%$ domestic audience reach (Pervyi kanal 2016) and a global audience of "more than 250 million in 190 countries," Channel One is "the most popular" Russian-language broadcaster (Channel One Russia n.d.). The channel is owned by the Federal Agency for State Property Management as well as by the National Media Group, a private media holding (National Media Group n.d.b). Among other shareholders are the TASS news agency, Ostankino Technical Center, and Russian oligarch Roman Abramovich (Dziadul 2018). Reportedly, 47\% of Russia's domestic audience get their news from this channel (Volkov and Goncharov 2019).

Founded in 1993, NTV was a prominent critic of the state until the ruling regime initiated a "purge" of the channel in 2001 (Traynor 2001). Since the Russian government-owned Joint Stock Company Gazprom appropriated NTV, the broadcaster has transformed from a critic of the state into a loyal voice of the ruling regime. According to NTV's LinkedIn profile, the channel's audience across the former Soviet bloc includes 100 million people. Among the global satellite broadcasters, NTV is "the main Russian language channel" (NTV Broadcasting Company n.d.), while 36\% of Russia's domestic audience get their news from this channel (Volkov and Goncharov 2019).

REN TV was founded as a brand on January 1,1991, and has been airing in Russia since 1997 (REN TV n.d.). Like Channel One, REN TV is majority owned by the National Media Group with $82 \%$ of the shares (National Media Group 2016). The owners estimate that the channel is "potentially" available to 120 million people, while its website is "one of the most cited in the Russian market" with the reach of "2 million of unique visitors per day" (National Media Group n.d.a). REN TV is a source of news for $17 \%$ of Russia's domestic audience (Volkov and Goncharov 2019).

Launched in 2006, Rossiia 24 channel operates under the All-Russia State Television and Radio Broadcasting Company (VGTRK). According to its owners, the channel "has the leading position at the national broadcasting market, and is one of the leading producers of content" (VGTRK n.d.). Specializing solely in 24/7 news delivery to an audience of 50 million people (Media International Russia n.d.), Rossiia 24 is a sister channel of another influential channel owned by VGTRK, Rossiia 1. The online archive of Rossiia 24's news program Vesti (The News) contained pieces that were aired both on Rossiia 24 and Rossiia 1. Rossiia 24 is a source of news for $31 \%$ of Russia's domestic audience, while a reported $48 \%$ receive their news from Rossiia 1 (Volkov and Goncharov 2019).

Founded in 2010, TV Rain is a unique phenomenon in Russian broadcasting that positions itself as a platform designed "for those who care" (TV Rain n.d.a). During the anti-Kremlin protests of 2011 and 2012 (Chalsty and Whitefield 2013), TV Rain openly covered the events. Russia's television providers unplugged the "liberal-leaning" TV Rain in 2014 amid a scandal surrounding a public poll that the channel carried out (RIA Novosti 2014). TV Rain is currently limited to online streaming and 
much of its content is paid; in 2016 the number of registered paying viewers was 72,000 people (Sat-World.net 2016). Only 1\% of Russia's domestic audience gets their news via TV Rain (Volkov and Goncharov 2019). ${ }^{9}$

\section{STOPXAM IN TRADITIONAL MEDIA}

While this study employs qualitative approaches to media content analysis, some quantitative features such as the number and distribution of news reports featuring StopXam are helpful in illustrating the volume and frequency of coverage. As can be seen in Table 2, selected broadcasters differ in the frequency and volume of their reporting on StopXam.

Table 2. News items with coverage of StopXam, per broadcaster, disaggregated by year

\begin{tabular}{|c|c|c|c|c|c|c|c|c|c|c|c|c|}
\hline & \multicolumn{2}{|c|}{ Channel One } & \multicolumn{2}{|r|}{ NTV } & \multicolumn{2}{|c|}{ REN TV } & \multicolumn{2}{|c|}{ Rossiia 24} & \multicolumn{2}{|c|}{ TV Rain } & \multicolumn{2}{|c|}{ Totals } \\
\hline 2010 & 0 & $00 \%$ & 0 & $.00 \%$ & 0 & $0.00 \%$ & 2 & $0.65 \%$ & 0 & $00 \%$ & 2 & $0.65 \%$ \\
\hline 2011 & 0 & 0 & 0 & $0.00 \%$ & 0 & $0.0 c$ & 2 & $65 \%$ & 0 & 0.0 & 2 & $65 \%$ \\
\hline 2012 & 1 & $0.33 \%$ & 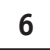 & 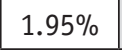 & 0 & . & 20 & 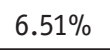 & 0 & .00 & 27 & $8.79 \%$ \\
\hline 2013 & 1 & $0.53 \%$ & 5 & $1.05 \%$ & 0 & 0.0070 & 19 & 0.1970 & 0 & $0.00 \%$ & 25 & $8.14 \%$ \\
\hline 2014 & 0 & $0.00 \%$ & 7 & $2.28 \%$ & 16 & $5.21 \%$ & 5 & $1.63 \%$ & 0 & $0.00 \%$ & 28 & $9.12 \%$ \\
\hline 2015 & 0 & $0.00 \%$ & 4 & $1.30 \%$ & 28 & $9.12 \%$ & 7 & $228 \%$ & 1 & 0.3 & 40 & $13.03 \%$ \\
\hline 2016 & 2 & $0.65 \%$ & 17 & 5. & 58 & $18.89 \%$ & 32 & 10. & 0 & $1.63 \%$ & 114 & 37 \\
\hline 2017 & 0 & $0.00 \%$ & 5 & $1.63 \%$ & 43 & $14.01 \%$ & 6 & $1.95 \%$ & 1 & $0.33 \%$ & 55 & $17.92 \%$ \\
\hline 2018 & 0 & $0.00 \%$ & 4 & $1.30 \%$ & 7 & $1.30 \%$ & 5 & - & 1 & $0.33 \%$ & 14 & $4.56 \%$ \\
\hline otals & 4 & $1.30 \%$ & 48 & $15.64 \%$ & 149 & $48.53 \%$ & 98 & $31.92 \%$ & 8 & $2.61 \%$ & 307 & $100.00 \%$ \\
\hline
\end{tabular}

Table 2 illustrates the number of reports per each broadcaster disaggregated by year in the period between January 1,2010, and December 31,2018. The majority of coverage comes from REN TV with $48.53 \%$ of news pieces; behind are Rossiia 24 with $31.92 \%$, NTV with $15.64 \%$, and TV Rain and Channel One with $2.61 \%$ and $1.30 \%$ respectively. The table also indicates that the coverage spikes across all platforms in 2016, the year when StopXam was initially liquidated by the decision of the Moscow City Court. The decision was overruled by the Supreme Court later that year, but applied again under the provision of the Moscow branch of the Ministry of Justice in 2018 (NTV 2018).

Russia's main broadcaster, Channel One, features four stories on StopXam in its online news archive. Two reports present the already mentioned sensational casesa conflict that took place in Moscow between the "activists" and the wife of Chechnya's deputy presidential plenipotentiary in Moscow, as well as the confrontation with the wife of the head of Mar'ino district of Russia's capital. The remaining two pieces report on the court decision to shut down StopXam. The incidents with politi-

9 The Levada Center report (Volkov and Goncharov 2019) does not specify whether the viewers access TV Rain content via the channel's website or its mobile application. 
cians' wives were widely covered by all selected broadcasters, while only TV Rain faced legal issues over copyright violation of StopXam, as the channel featured original footage from the group's YouTube channel (SecurityLab.ru 2012). StopXam's YouTube videos (edited by participants) often made it into the reports of other broadcasters, serving as evidence of what happened on the ground. Numerous online reports of state broadcasters in over a hundred instances provided direct links to the original videos on YouTube and links to the group's VKontakte ${ }^{10}$ page.

NTV, REN TV, and Rossiia 24 lead in the frequency of their reporting on StopXam. Despite the varying volume of the news items, these three broadcasters often report on the same cases and use similar language to describe, comment on, and frame the events. REN TV is the leader in coverage, with 149 news pieces responding to the majority of most notorious cases of StopXam's confrontations with drivers. Rossiia 24 has covered StopXam since the early days of the group's formation, with the first report dating back to June 2010. Rossiia 24's first report, dated June 22, 2010, quoted then mayor of Moscow, Iurii Luzhkov, describing StopXam as "useless." In this case, Luzhkov is somewhat of an outlier when it comes to representation of the ruling regime, as he was dismissed from his post in September 2010 over then President Medvedev's "loss of confidence" in his persona (Odynova 2010).

In its modest scope, TV Rain's coverage of StopXam is similar to that of Channel One. The online archive features eight news pieces covering StopXam's confrontations with the police; the court's liquidation of the group; Chugunov's political ambitions; and a "Sharia patrol" project "Stop Haram."11 Stop Haram is a curious case, as it was founded by former StopXam member Islam Ismailov and aimed to morally confront Muslims about life choices such as drinking alcohol and smoking. Chugunov denied any links between StopXam and Stop Haram, stating that several activists broke away due to "disagreements" and that Ismailov was "parasitically exploiting the brand" (Vesti 2017).

\section{THE GENESIS OF STOPXAM'S PORTRAYAL}

All selected platforms referred to StopXam participants as "activists" and as members of a "public movement." Words such as "project," "organization," "NG0," "volunteers," "youth," and "fighters" were used to describe the group. Several of the initial reports linked the "activists" to the pro-Kremlin youth movement Nashi. In this regard, NTV and Rossiia 24 featured meetings between StopXam and Russia's political leadership, represented by Putin and Medvedev. In 2011 Rossiia 24 reported on then President Medvedev's meeting with the "non-indifferent" youth activists and internet users (Skabeeva 2011). During the meeting StopXam leaders gave Medvedev one of their infamous stickers, suggesting he put it on the windshield of a bad driver. Such endorsement on national television granted informal powers to participants, as their acts were by default legitimized by the country's highest authority.

\footnotetext{
${ }_{10}$ Russia's analogue of Facebook.

11 "Haram" refers to things and activities forbidden in Islam.
} 
As can be seen in Figure 1, StopXam activists took a group photo with Putin in a "no tie" meeting. All but two participants are wearing branded StopXam sweatshirts and the stickers are displayed in the background. Wearing a long-sleeved shirt depicting the first man in space, Soviet cosmonaut Yury Gagarin, is StopXam's leader Chugunov. The woman in a scarlet dress, not facing the camera, is the group's former spokesperson Mitrofanova.

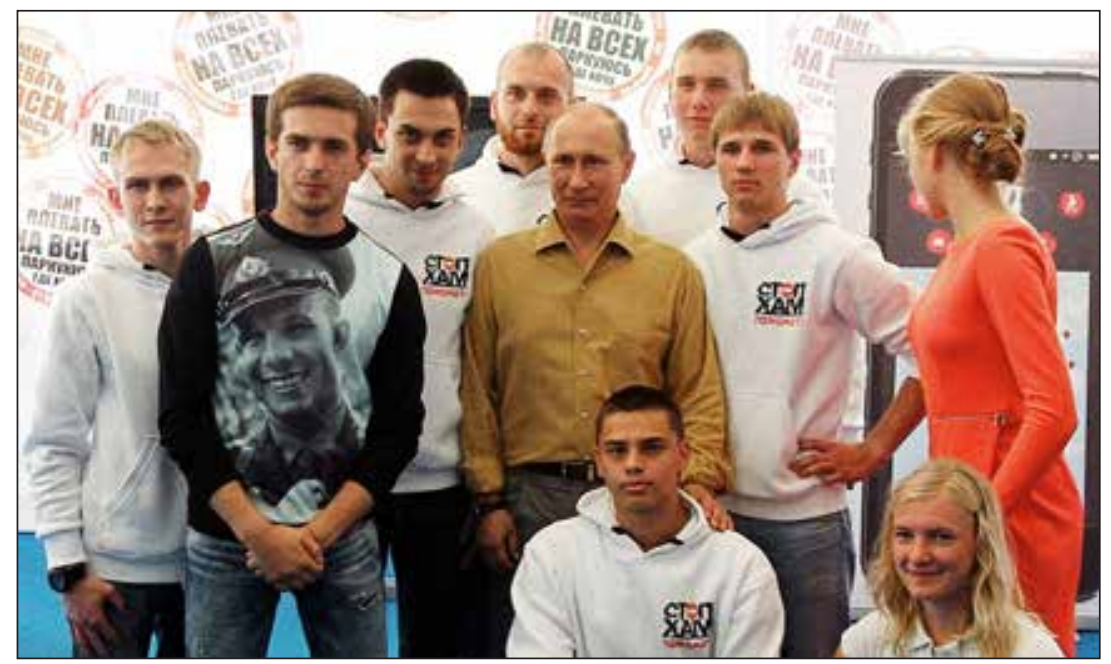

Figure 1. Vladimir Putin with StopXam participants and founders. Photo credit: Mikhail Kliment'ev/ITAR-TASS

In the majority of the reports, coverage concerned Russia's capital, the city of Moscow, and its second largest city and historical capital, Saint Petersburg. News reports on NTV, REN TV, and Rossiia 24 covered StopXam "raids" across the country, namely in Bashkortostan, Chelyabinsk, Karelia, Khabarovsk, Omsk, Perm', Petrozavodsk, Voronezh, and other locations. News pieces covering cases from the "periphery," as a rule, implied coverage of the newly established StopXam branches, scandalous cases taking place in the regions, or both types of events in a single report.

\section{TARGETS AND RETALIATION}

Throughout the reports, targets of StopXam have included businessmen and businesswomen, singers, athletes, porn stars, politicians and their relatives (spouses, children, and grandchildren), and other famous and nonfamous people. On several occasions StopXam targeted police officers. All broadcasters except TV Rain have framed targets as aggressive, guilty, and/or rich.

Female targets have dominated the reports on the four state broadcasters. None of REN TV's 149 reports on StopXam covered in this research assumed the potential innocence of targets. In its reports, TV Rain emphasized the violence performed by participants and underscored the fact that targets' guilt was "alleged" and offences were "perceived." The remaining broadcasters framed targets as "po- 
tentially innocent" on a couple of occasions each. NTV, REN TV, and Rossiia 24 framed female drivers as "inadequate," referring to them as "damochka" (missy), "autolady," or "a blonde." Male drivers were not described in terms of hair color or as "automen."

Figure 2 illustrates a report by REN TV (2018) featuring female targets of StopXam. The report is titled "In Moscow Ladies behind the Wheel Have Aggressively Reacted to the Remark of 'StopXam' Activists." The subtitle states, "One of them started threatening with some powerful connections." The "catch" line in the first two sentences of the report states that "In Moscow, stubborn and vicious gals attacked sidewalks with their cars. They responded aggressively to any inquiry made by social activists [StopXam]." The material is presented as "exclusive" and is accompanied by the tags "Moscow" and "activists." This particular report, like most REN TV reports, features footage taken and edited by participants.

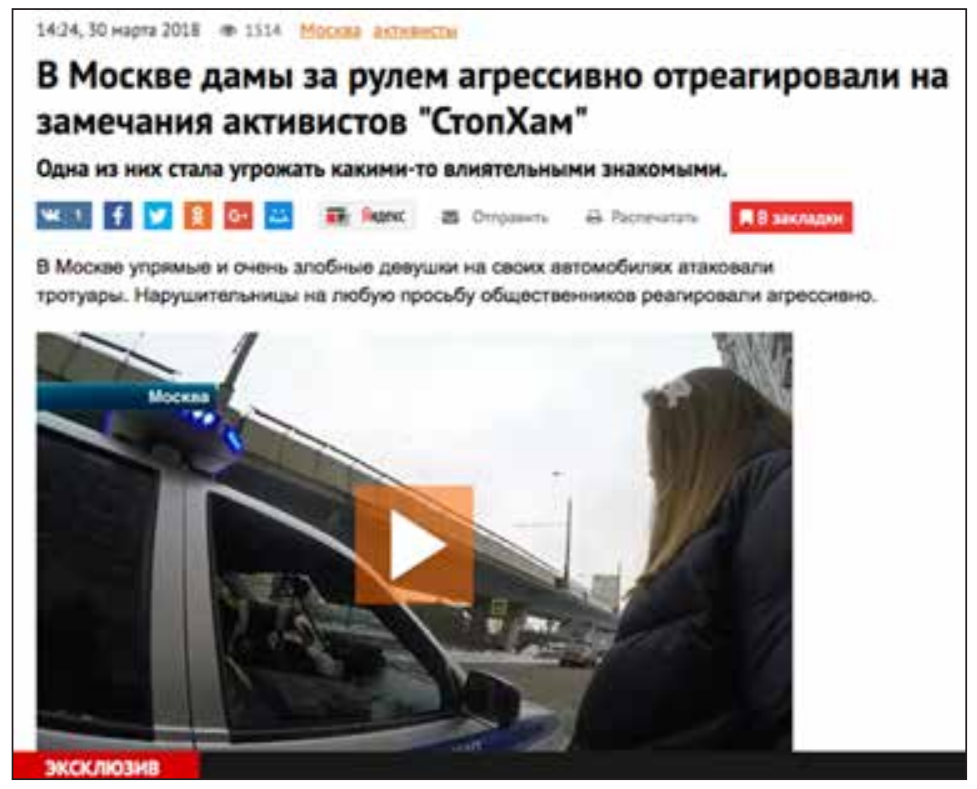

Figure 2. REN TV report screenshot. Gender biases in the reports

Presumption of guilt of the targets, exposure of their identity, and gendered commentary were also prevalent on Rossiia 24. Figure 3 illustrates a report titled "The Blonde from around the Corner" (Blinnikov 2013). ${ }^{12}$ The report features footage from StopXam's YouTube channel and states the following:

She drove over a foot, gave a ride on the hood, and went on to a physical attack. All of this was performed by a heroine of a scandalous video that appeared online-a Saransk-native, 31-year old [the report provides the target's full name]

12 The title is an allusion to the 1984 Soviet romantic comedy The Blonde around the Corner. 
owner of a snow-white Audi. In this very car, the fragile blonde tried to detour the traffic via a sidewalk.

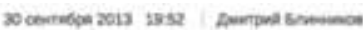

Бпондинка из-за чгла
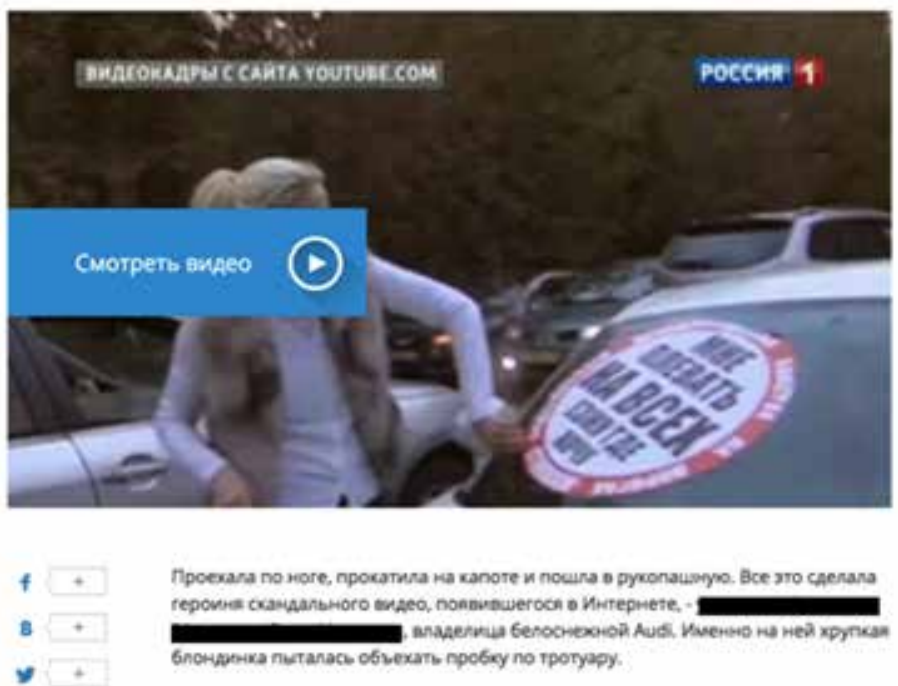

Figure 3. Rossiia 24 screenshot. Target's personal information disclosed (redacted by the author)

Beyond gender and appearance markers, the targets are described through the Soviet-era term of being owners of an inomarka (a foreign-made car), which underscores the higher socioeconomic status of the driver. Vehicles are described as being "expensive" and "elite." Some reports describe the gender, socioeconomic status, and ethnic background of the target. NTV report titled "'Nashi' versus the Chechens: Scandalous Video Stirred Up the Internet" (NTV 2012) sets up an "us versus them" contestation wherein the Chechens are framed as a group distinct from Russians, turning the parking violation into an interethnic matter. Once again NTV features video footage from StopXam's YouTube channel, which contributes to further one-sided framing of the events, as the account is informed through the perspective of participants. The target is portrayed as an aggressive, rude, rich, power abuser and is quoted to have threatened the activists. This particular case features the wife of the Chechnya's deputy presidential plenipotentiary to Moscow and was also widely covered by REN TV, Rossiia 24, and Channel One. As a result of this incident, the deputy plenipotentiary lost his job, while his wife was further shamed by the President of Chechnya Ramzan Kadyrov who accused the target of "acting in a manner not suitable for the Chechen mentality"; Kadyrov emphasized that "as a Chechen woman, she should have known that all this is contrary to our moral and ethical standards" (Vesti 2012). 
These cases demonstrate how, by entering traditional media discourse, the incidents are further framed from the perspective of participants and lead to reactions from state leadership. Female targets experience pressure of societal norms that still find it somewhat unusual to see that a woman is driving a car, hence the term "autolady," as well as the pressure of having to conform to special moral and ethical standards.

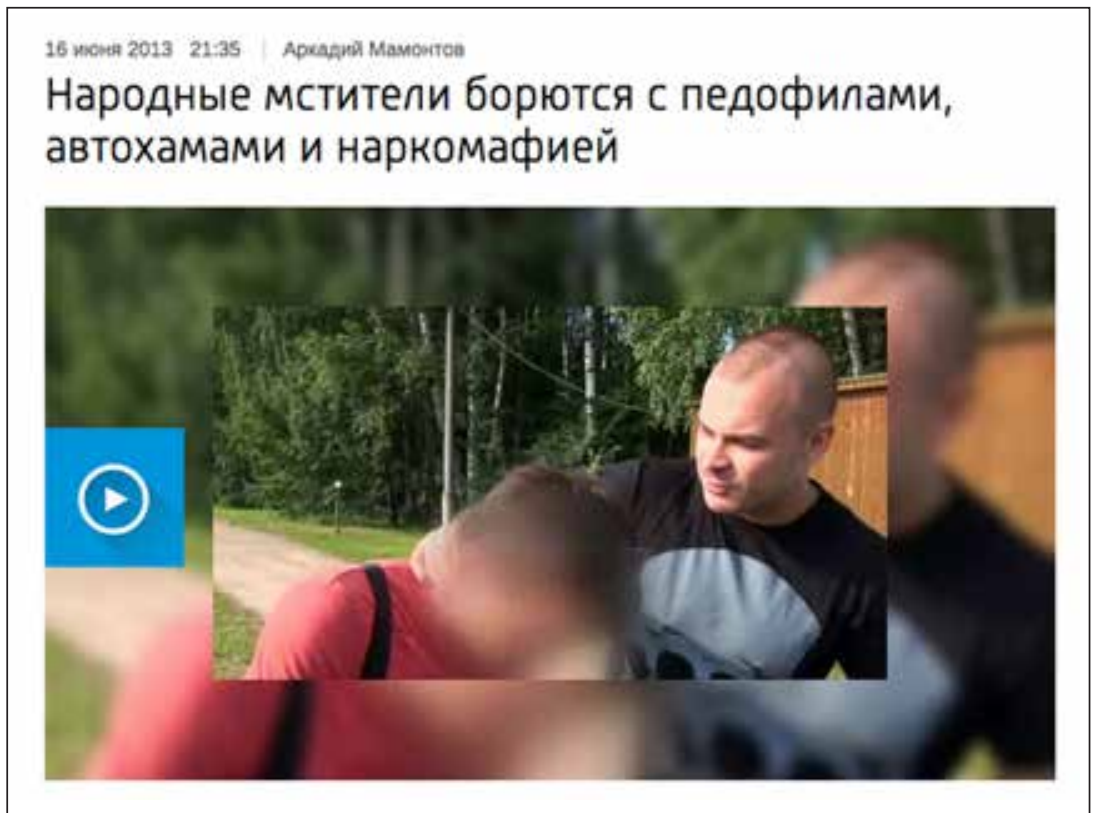

Figure 4. Rossiia 24 report screenshot. Tesak (Axel), founder of hate-based vigilante formation, is featured on national television in the process of humiliating his target

Whereas NTV, REN TV, and Rossiia 24 all report on the dysfunctionality and inactivity of law enforcement, Rossiia 24 is the only platform that quoted one of the youth activists accusing police forces of direct collaboration with criminals. As such, an article dated June 16, 2013, reported on "people's avengers fighting pedophiles, road bores, and drug mafia" (Mamontov 2013). The report lumped numerous vigilante formations in Russia, including antimigrant and neo-Nazi vigilante movements ${ }^{13}$ alongside Kremlin-supported groups, into a single force of "citizen-led justice." Thus, traditional media provide a platform for openly criminal participants who use social media to "intimidate and humiliate their targets" (Kasra 2017:186) to express their views on national television. In the same report a StopXam representative states that police are afraid of approaching cars with "cool license plates." Traditional media, therefore, provide justification for vigilantism when they frame police forces as dysfunctional and vigilantes as superheroes-"the avengers."

${ }^{13}$ For a detailed account of these groups and their entrepreneurship in vigilantism, see Favarel-Garrigues (2019). 
All platforms, except for Channel One, have reported on police becoming target to StopXam. Figure 5 illustrates a 2014 NTV report from Karelia where "a StopXam activist was detained for placing the sticker on a police car" (NTV 2014).

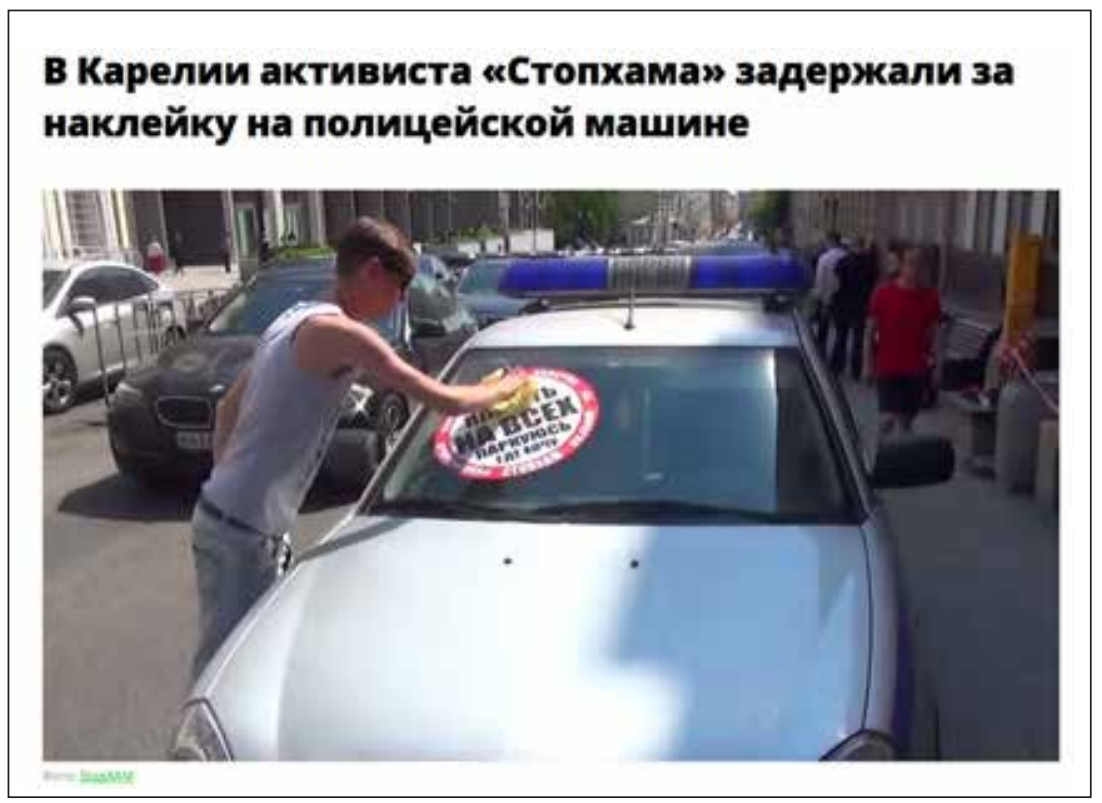

Figure 5. NTV report screenshot. Police as target

NTV and Rossiia 24 reported on the "internationality" of the "movement" with branches established in neighboring states. The stickers are mentioned as the main retaliation tool in almost all reports of all broadcasters. Rossiia 24 reported both on the fact that the stickers were easy to remove and on the fact that removal "takes time and effort," indicating lack of objectivity in controversies surrounding this form of retaliation. The reports also mention "moralization" and "online exposure" as part of the group's activist repertoire. When it comes to physical confrontations and fights, the majority of coverage framed targets as the ones attacking participants.

\section{DIFFERENT VOICES AND SHIFTING PERSPECTIVES}

As far as the granting of voice is concerned, of all actors involved, StopXam leader Chugunov was given the most chances to comment on incidents and processes surrounding the group. NTV and Rossiia 24 gave voice to the Ministry of Internal Affairs to comment, while only NTV featured an anti-StopXam citizen activist speaking up and communicating his views on the group amid the court decision to shut it down. StopXam's voice was represented by Chugunov or other members who were interviewed or quoted from their social media posts and TV appearances. In the case of targets, their voices were presented in the form of quoted speech from videos produced and edited by StopXam participants. This 
means that in spite of the perceived presence of the targets' voice, the message is subjected to manipulation by participants and broadcasters. When it comes to the voices of police officers, only Rossiia 24 provided a platform for them. In these reports police communicated through official statements made by their press services. In all reports featuring such press statements, StopXam members were presented as the instigators of conflict.

It is curious to note that every report featuring lawyers as commentators and police as targets framed the participants as hooligans and inferred avaricious motives behind their activism. Rossiia 24 accused StopXam of removing a self-incriminating video (GTRK “Kareliia" 2015) and quoted Karelia's internal affairs minister accusing StopXam of hooliganism and damaging private property (Vesti 2015).

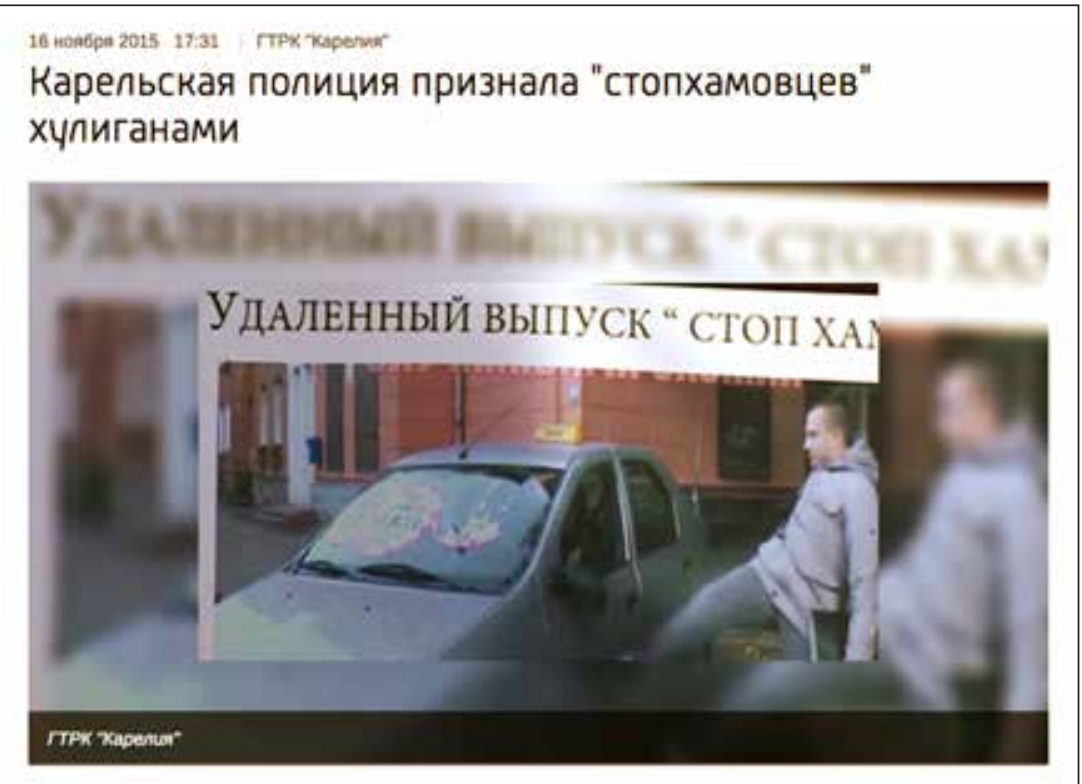

Figure 6. Rossiia 24 report screenshot. Police in Karelia pronounced StopXam as "hooligans"

In this report the lawyers are quoted stating that StopXam participants violate the law, slander their targets, practice mob rule, and block the vision of drivers by placing stickers on their windshields. Beyond these accusations, the monetization of YouTube videos featuring famous people is addressed in the report by NTV presented in Figure 7: "StopXam is making tens of thousands of dollars on scandalous videos with celebrities" (NTV 2016c). 


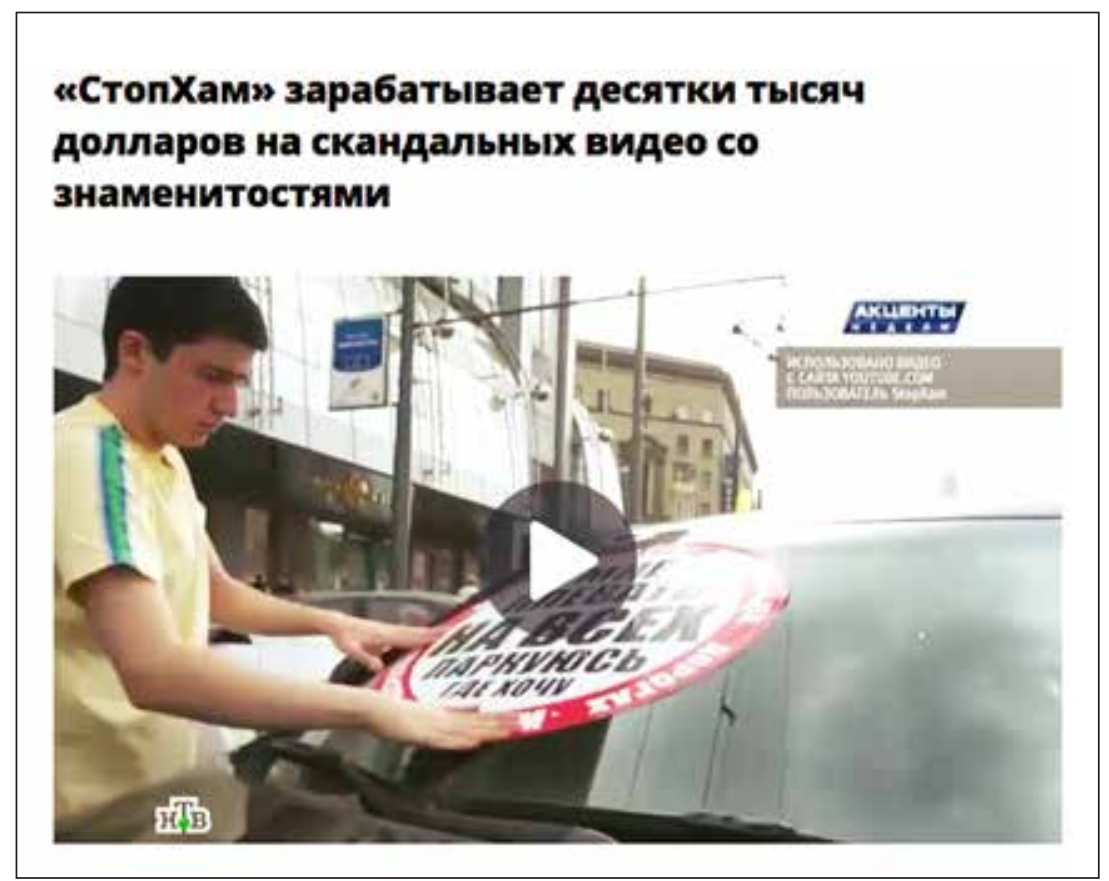

Figure 7. NTV report screenshot. StopXam's motives are questioned

A lawyer featured in this report breaks down the nature of activities of this "organized movement" and is quoted next to "anti-StopXam" activists (NTV 2016c). The report estimates that on YouTube alone participants make tens of thousands of US dollars per month on top of presidential grants. Subsequent reports continue to question StopXam's motives and approaches, reminding the audience that StopXam was liquidated by the Moscow City Court and that its members are infamous for fights and aggression in their videos, especially when it comes to celebrities (NTV 2016a).

\section{HEROES OR HOOLIGANS? MEDIA REVELATIONS}

The portrayal and framing of StopXam in Russia's traditional media are rather inconsistent and fluctuate across time and broadcasters. In 2016 StopXam received the most mentions in the news: it was the year when the group confronted a prominent Russian athlete and Olympic champion. While other rich and famous people had been approached by participants in the past, the case of the confrontation with this athlete is distinct, as athletes occupy an important niche in the process of authoritarian nation building (see, for instance, Koch 2013). Mega sporting events and athletes' achievements help Russia construct its image as a superpower, even though the price tag that comes along with this ambition is very high (Puddington 2017). Thus, having put an Olympic champion on the ground during a fight, StopXam activists essentially assaulted Russia's national pride. Such a bold move could have served as the trigger for scrutiny of the group, which had otherwise enjoyed the endorsement and support of the state and its media. Having crossed this unspoken boundary, StopXam 
demonstrated that it might be more ferocious than the ruling regime hoped when it initially endorsed the group. In 2016 StopXam was liquidated as a legal entity. Although this decision was overruled by the Supreme Court six months later, liquidation was, nevertheless, reinforced in 2018. NTV, REN TV, and Rossiia 24 aired news on StopXam following the court decision, reporting that their "raids" and activities would continue in spite of the liquidation.

Per StopXam itself, it is unclear who specifically ordered their liquidation. Following the court decision, Chugunov gave several interviews where he spoke about the fact that StopXam had targeted public servants and parliament members, bandits, police, prosecutor's office employees, and even the head of Medvedev's secretariat. Chugunov mentioned that on several occasions StopXam was offered millions of rubles in bribes to not upload videos to YouTube but refused such offers. In the same interview he denounced Russia's ruling party Edinaia Rossiia (United Russia), announced his participation in the parliamentary election, and promised to open "new formats, new channels, new leaders" in a variety of directions countering "bores" (Pasmi.ru 2016). This interview was not featured on the news platforms covered by current research. Chugunov indeed ran in the 2016 parliamentary election but came in second to last in his electoral district, in tenth place. As of 2017, Chugunov no longer serves in the Civic Chamber.

\section{CONCLUSION}

This article has sought to achieve three objectives-to test the existing conceptual framework of digital vigilantism using the example of StopXam; to investigate the nature of portrayal of vigilantes, their targets, and police forces in Russia's stateowned and independent media; and to evaluate the role of traditional media in digital vigilantism manifestation.

Having compared StopXam against the existing definitional characteristics of digital vigilantism, the article makes a contribution by demonstrating the significance of audience in mediated retaliation. Exposure to wider audiences amplifies the harms experienced by targets and can lead to consequences that conventional encounters with legal police forces would not necessarily yield. In this regard, traditional media plays an important role in framing cases and granting voice to actors involved.

Content analysis demonstrates the important role of traditional media in framing social justice and in giving voice to respective actors. In the case of digital vigilantism, where mediated exposure is at the core of retaliation, traditional media can be an important stage for targets to deliver their side of the story. Given their vast social media following, StopXam possess enormous capacities in exposing their targets. In such cases, if the target wants to tell their side of the story to the masses, traditional media is one of the few channels available to them. However, this channel is jeopardized when featured stories are delivered from a one-sided and biased perspective of StopXam participants.

When it comes to framing of respective actors, StopXam's portrayal was not a consistent or homogeneous matter. State leadership, represented by Medvedev and 
Putin, expressed support for StopXam and other similar groups that came out of Nashi youth movement. Such endorsement, broadcast on national television, granted informal powers to participants as their acts were automatically legitimized. While all broadcasters referred to the group as "activists" and a "public movement," descriptions such as "organization," "project," "scandalous organization," "NGO," "concerned citizens," and "fighters" were also prevalent. Reports on all platforms peaked in 2016 amid the scandal involving StopXam's retaliation against Russia's most prominent athlete. Following the incident, news reports began questioning the motives of StopXam participants, some of the reports openly accusing them of being avaricious, benefiting from large state grants and the monetization of "scandalous" videos on YouTube.

TV Rain faced copyright issues with StopXam for featuring the group's YouTube videos in its reports, while other platforms systematically featured the same footage and faced no issues. Furthermore, platforms such as YouTube play an important role in providing a stage for vigilantes and in allowing StopXam participants to generate income from their activities while the privacy of targets is violated.

Unlike TV Rain, broadcasters such as NTV, REN TV, and Rossiia 24 employed a bias against female targets by highlighting their physical features, referring to them as "the blonde" or "a fragile gal." The term "autolady" was used in reference to female drivers, hinting at the special circumstances of participants dealing with a female driver. Female targets were also portrayed as aggressive, scandalous, and incompetent at driving. Targets' personal information such as full name, age, and license plates were systematically disclosed in the reports.

The "rich and powerful" of Russian society were framed through references to their social status - politicians, singers, athletes, prominent businessmen/women, or relatives of the above. Their vehicles were described as "expensive," "elite," "with special license plates," and "foreign made." Some reports portrayed police as dysfunctional, which provided further justification for vigilantes' role and acts of social justice. State media did not shy away from referring to targets by their ethnic origins such as "the Chechens." Because in some cases confrontation with StopXam and subsequent media attention led to targets losing their jobs, the power of exposure in retaliation is once again evident. If violators are approached by police for parking in the wrong place, they would normally be issued a fine, which they would then pay and go on with their lives. In mediated exposure, the price of parking in the wrong place is much higher. Digital vigilantism is a phenomenon where each wave of exposure can harm individuals.

Reporting on the road-traffic related cases through the frame of "anarchy exercised by elite citizens on expensive cars" is a scenario that speaks to the greater masses in Russia. References to "Chechens" and "inadequate female drivers" hold anecdotal significance in a society where gender biases and interethnic confrontations are familiar points of discussion. Perhaps, reports featuring young people confronting the "rich and famous" of society serve the purpose of presenting a sense of justice to the greater masses-so long as the confronted targets are not the ruling elite itself. 
Explaining why selected state broadcasters framed actors in a specific manner in the specific period of time is a challenge that requires further investigation through interviews with journalists, editors, and other media professionals in Russia. What can be elaborated at this point is the fact that in the current state of Russian media there are unspoken rules for what can and cannot be said on state television. At the same time, broadcasters enjoy a level of autonomy on certain topics. During the time when StopXam was openly endorsed by state leadership, most of the reports on state television framed the group as a volunteer formation of young activists. The narratives in state media shifted and started to question the motives of StopXam amid the deterioration of relations between vigilantes and the state.

This research contributes to current literature on vigilantism by addressing a case where a vigilante group has turned into a brand-like formation with branches across and beyond Russia. StopXam is a unique movement in the sense that it is in possession of power to inspire and endorse similar movements around the world. Conversations with members and branch founders beyond Russia revealed that when launching their own initiatives, people feel the need for StopXam's approval. Furthermore, StopXam's success makes it a recognizable movement to the point that affiliating oneself with the existing brand appears to make more sense than founding a unique initiative. Whether StopXam members are heroes or hooligans is a contested view, and media analysis reveals that perceptions have changed over time.

Future research is needed on media portrayal of other vigilante formations in Russia and beyond. Comparative studies involving different groups nationally and internationally can shed light further on the role and place of traditional media in digital vigilantism. Other avenues for exploration could include qualitative content analysis of videos produced by vigilantes in order to identify their frames and biases and to compare them with framings in traditional media. Relations between vigilantes and social media platforms require further investigation.

\section{REFERENCES}

Altheide, David L., and Christopher J. Schneider. 2013. Qualitative Media Analysis. 2nd ed. Thousand Oaks, CA: SAGE Publications.

Atwal, Maya, and Edwin Bacon. 2012. “The Youth Movement Nashi: Contentious Politics, Civil Society, and Party Politics." East European Politics 28(3):256-266. doi:10.1080/21599165.2012.6 91424.

Carroll, Craig E. 2016. “Mapping the Contours of the Third Level of Agenda Setting: Uniplex, Duplex and Multiplex Associations." Pp. 34-53 in The Power of Information Networks: New Directions for Agenda Setting, ed. by Lei Guo and Maxwell McCombs. New York: Routledge.

Chalsty, Paul, and Stephen Whitefield. 2013. “Forward to Democracy or Back to Authoritarianism? The Attitudinal Bases of Mass Support for the Russian Election Protests of 2011-2012." PostSoviet Affairs 29(5):387-404. doi:10.1080/1060586X.2013.807605.

Cheong, Pauline Hope, and Jie Gong. 2010. “Cyber Vigilantism, Transmedia Collective Intelligence, and Civic Participation." Chinese Journal of Communication 3(4):471-487. doi:10.1080/17544 750.2010 .516580 .

Chong, Dennis, and James N. Druckman. 2007. "Framing Theory." Annual Review of Political Science 10:103-126. doi:10.1146/annurev.polisci.10.072805.103054.

Entman, Robert M. 2007. "Framing Bias: Media in the Distribution of Power." Journal of Communication 57(1):163-173. 
Favarel-Garrigues, Gilles. 2019. "Digital Vigilantism and Anti-Paedophile Activism in Russia: Between Civic Involvement in Law Enforcement, Moral Policing and Business Venture." Global Crime. doi:10.1080/17440572.2019.1676738.

Favarel-Garrigues, Gilles, and Anne Le Huérou. 2004. “State and the Multilateralization of Policing in Post-Soviet Russia." Policing and Society 14(1):13-30.

Gabdulhakov, Rashid. 2018. “Citizen-Led Justice in Post-Communist Russia: From Comrades' Courts to Dotcomrade Vigilantism." Surveillance \& Society 16(3):314-331.

Gabdulhakov, Rashid. 2019. “In the Bullseye of Vigilantes: Mediated Vulnerabilities of Kyrgyz Labour Migrants in Russia." Media and Communication 7(2):230-241. doi:10.17645/mac.v7i2.1927.

Guo, Lei. 2016. "A Theoretical Explication of the Network Agenda Setting Model: Current Status and Future Directions." Pp. 3-19 in The Power of Information Networks: New Directions for Agenda Setting, ed. by Lei Guo and Maxwell McCombs. New York: Routledge.

Hemment, Julie. 2012. “Nashi, Youth Voluntarism, and Potemkin NGOs: Making Sense of Civil Society in Post-Soviet Russia." Slavic Review 71(2):234-260. doi:10.1017/S0037677900013607.

Hutchings, Stephen, and Joanna Szostek. 2016. "Dominant Narratives in Russian Political and Media Discourse during the Ukraine Crisis." Pp. 183-196 in Ukraine and Russia: People, Politics, Propaganda and Perspectives, ed. by Agnieszka Pikulicka-Wilczewska and Richard Sakwa. Bristol, UK: E-International Relations Publishing.

Johnston, Les. 1996. “What Is Vigilantism?" The British Journal of Criminology 36(2):220-236.

Kasra, Mona. 2017. "Vigilantism, Public Shaming, and Social Media Hegemony: The Role of DigitalNetworked Images in Humiliation and Sociopolitical Control." The Communication Review 20(3):172-188. doi:10.1080/10714421.2017.1343068.

Koch, Natalie. 2013. "Sport and Soft Authoritarian Nation-Building." Political Geography 32:42-51. doi:10.1016/j.polgeo.2012.11.006.

Meraz, Sharon. 2016. "An Expanded Perspective on Network Agenda Setting between Traditional Media and Twitter Political Discussion Groups in 'Everyday Political Talk.'" Pp. 66-88 in The Power of Information Networks: New Directions for Agenda Setting, ed. by Lei Guo and Maxwell McCombs. New York: Routledge.

McCombs, Maxwell E., and Donald L. Shaw. 1972. "The Agenda-Setting Function of Mass Media." Public Opinion Quarterly 36(2):176-187.

Mijnssen, Ivo. 2014. The Quest for an Ideal Youth in Putin's Russia: History, Modernity, and Patriotism according to Nashi, 2005-2013. Vol. 1, Back to Our Future! 2nd ed. Stuttgart, Germany: IbidemVerlag.

Moncada, Eduardo. 2017. "Varieties of Vigilantism: Conceptual Discord, Meaning and Strategies." Global Crime 18(4):403-423. doi:10.1080/17440572.2017.1374183.

Oates, Sarah. 2016. "Russian Media in the Digital Age: Propaganda Rewired." Russian Politics 1(4):398-417. doi:10.1163/2451-8921-00104004.

Oleinik, Anton. 2016. "Corruption on the Road: A Case Study of Russian Traffic Police." IATSS Research 40(1):19-25. doi:10.1016/j.iatssr.2015.12.001.

Orttung, Robert W., and Christopher Walker. 2013. "Putin and Russia's Crippled Media." Russian Analytical Digest 123:2-5.

Rosenbaum, H. Jon, and Peter C. Sederberg. 1974. "Vigilantism: An Analysis of Establishment Violence." Comparative Politics 6(4):541-570.

Smallridge Joshua L., Philip Joseph Wagner, and Justin Nicholas Crowl. 2016. “Understanding Cyber-Vigilantism: A Conceptual Framework." Journal of Theoretical \& Philosophical Criminology 8(1):57-70.

Starks, Helene, and Susan Brown Trinidad. 2007. "Choose Your Method: A Comparison of Phenomenology, Discourse Analysis, and Grounded Theory." Qualitative Health Research 17(10):13721380.

Stratton, Greg, Anastasia Powell, and Robin Cameron. 2017. “Crime and Justice in Digital Society: Towards a 'Digital Criminology'?" International Journal for Crime, Justice and Social Democracy 6(2):17-33. doi:10.5204/ijcjsd.v6i2.355. 
Tolz, Vera, and Yuri Teper. 2018. “Broadcasting Agitainment: A New Media Strategy of Putin's Third Presidency." Post-Soviet Affairs 34(4):213-227. doi:10.1080/1060586X.2018.1459023.

Trottier, Daniel. 2017. “Digital Vigilantism as Weaponisation of Visibility." Philosophy \& Technology 30(1):55-72. doi:10.1007/s13347-016-0216-4.

Trottier, Daniel. 2019. “Denunciation and Doxing: Towards a Conceptual Model of Digital Vigilantism." Global Crime. doi:10.1080/17440572.2019.1591952.

Wilson, Deborah G., Olga Kolennikova, Leonid Kosals, Rozalina Ryvkina, and Yu. Simagin. 2008. "The 'Economic Activities' of Russian Police." International Journal of Police Science \& Management 10(1):65-75.

\section{SOURCES}

A. P. 2018. "Vigilantskie organizatsii: Proiskhozhdenie i formy aktivnosti." Vigilanty, proekt fonda "Obshchestvennyi verdikt," June 20. http://vigilant.myverdict.org/cases/typology.

Blinnikov, Dmitrii. 2013. “Blondinka iz-za ugla." Vesti.ru, September 30. https://www.vesti.ru/videos/show/vid/541783/.

Channel One Russia. N.d. “Always Number One!" Accessed October 18, 2019. http://eng.1tv.com/ history.

“Dos'e: StopXam." N.d. Vigilanty, proekt fonda "Obshchestvennyi verdikt." Accessed October 18, 2019. http://vigilant.myverdict.org/files/stop-ham.

Dziadul, Chris. 2018. "Financial Woes at Russia's Channel One." Broadband TV News, November 19. https://www.broadbandtvnews.com/2018/11/19/financial-woes-at-russias-channel-one/.

GTRK "Kareliia." 2015. “Karel'skaia politsiia priznala 'stopxamovtsev' khuliganami." Vesti.ru, November 16. http://www.vesti.ru/doc.html?id=2687423.

Mamontov, Arkadii. 2013. "Narodnye mstiteli boriutsia s pedofilami, avtokhamami i narkomaniei." Vesti.ru, August 2. http://www.vesti.ru/doc.html?id=1095318.

Media International Russia. N.d. “Reklama na TV.” Accessed October 18, 2019. http://mediainrussia.com/rossiya_24.

Moscow Times. 2019. "Russian Media Ordered to Delete Protest Videos over 'Extremist' YouTube Comments." May 29. https://www.themoscowtimes.com/2019/05/29/russian-media-ordered-to-delete-protest-videos-over-extremist-youtube-comments-a65789.

National Media Group. 2016. "National Media Group Completes the Consolidation Process of the Izvestia Shares." NMG press release, August 1. https://nm-g.ru/en/press/37/267/?sphrase_ id $=2087$.

National Media Group. N.d.a. "REN TV-One of the Largest National Private Channels." Accessed October 18, 2019. https://nm-g.ru/en/actives/sections.php?ID_BLOCK=33\&ID_SECTION=76.

National Media Group. N.d.b. “Subsidiaries." Accessed October 18, 2019. http://nm-g.ru/en/actives/.

NTV. 2012. “'Nashi' protiv chechentsev: Skandal'noe video vskolykhnulo Internet." May 2. http:// www.ntv.ru/novosti/294769/.

NTV. 2013. “Putinu ponravilis' ‘StopXamovskie' prilozheniia dlia mobil'nykh telefonov.” August 2. https://www.ntv.ru/novosti/638757/.

NTV. 2014. “V Karelii aktivista 'StopXam' zaderzhali za nakleiku na politseiskoi mashine." September 9. http://www.ntv.ru/novosti/1210222/.

NTV. 2016a. "Aktivisty 'StopXama' atakovali avtobus s omonovtsami v Moskve." March 31. http:// www.ntv.ru/novosti/1618062/.

NTV. 2016b. “Gimnast Aleksei Nemov podralsia s aktivistami 'StopXama': Video." February 15. http://www.ntv.ru/novosti/1606318/.

NTV. 2016c. "'StopXam' zarabatyvaet desiatki tysiach dollarov na skandal'nykh video so znamenitostiami." February 21. http://www.ntv.ru/novosti/1607982/.

NTV. 2018. "Osnovatel' likvidirovannogo 'StopXama' nazval novoe pole boia." September 21. https://www.ntv.ru/novosti/2076461/. 
NTV Broadcasting Company. N.d. “About Us." LinkedIn. Accessed October 19, 2019. https://www. linkedin.com/company/ntv-broadcasting-company/.

Odynova, Alexandra. 2010. “Luzhkov Fired over 'Loss of Confidence.'” Moscow Times, September 29. https://themoscowtimes.com/news/luzhkov-fired-over-loss-of-confidence-1778.

Pasmi.ru. 2016. “Osnovatel' dvizheniia 'StopXam' Dmitrii Chugunov: Predlagali milliony, no reputatsiia dorozhe." May 23. https://pasmi.ru/archive/142529/.

Pervyi kanal. 2016. "Zony veshchaniia Pervogo kanala." February 19. https://www.1tv.ru/about/ broadcast-area.

Puddington, Arch. 2017. “The Games Autocrats Play." Freedom House blog, September 18. https:// freedomhouse.org/blog/games-autocrats-play.

REN TV. 2018. “V Moskve damy za rulem agressivno otreagirovali na zamechanie aktivistov 'StopXam.'" March 30. http://ren.tv/novosti/2018-03-30/v-moskve-damy-za-rulemagressivno-otreagirovali-na-zamechaniya-aktivistov-stopham.

REN TV. N.d. “0 kanale.” Accessed November 13, 2020. https://ren.tv/tv-channel/about.

RIA Novosti. 2014. "Cable, Satellite Companies Pull Russian TV Station over Poll." Sputnik News, January 29. https://sputniknews.com/russia/20140129187032369-Cable-Satellite-Companies-Pull-Russian-TV-Station-Over-Poll/.

Sat-World.net. 2016. "Nazvano nyneshnee kolichestvo podpischikov telekanala 'Dozhd'." February 23. http://sat-world.net/1360-nazvano-nyneshnee-kolichestvo-podpischikov-telekanala-dozhd.html.

SecurityLab.ru. 2012. “Telekanal 'Dozhd' zablokirovan na YouTube za narushenie avtorskikh prav." May 14. https://www.securitylab.ru/news/424406.php.

Skabeeva, Ol'ga. 2011. "Medvedev vstretilsia s neravnodushnymi internet-pol'zovateliami." Vesti.ru, November 9. http://www.vesti.ru/doc.html?id=625511.

Smimimi Russia. 2012. “Oksana Mitrofanova iz 'StopXam'—dlia 'Smimimi.'” Posted July 11. Video, 7:59. https://www.youtube.com/watch?v=Co2UJ1gfnsY.

Sokolov, Nikolai. 2019. "Agressivnykh bloggerov i aktivistov predlozheno sdelat' druzhinnikami." Vesti.ru, June 25. https://www.vesti.ru/videos/show/vid/802189/.

Stop a Douchebag. N.d. Accessed October 19, 2019. https://stopadouchebag.org/.

StopXam. 2017. “StopXam Instruktsiia \#1—otkrytie filiala dvizheniia." Posted July 19. Video, 1:56. https://www.youtube.com/watch?v=-yRikILhKSI.

StopXam. 2018. "StopXam Peru—kak rabotaet StopXam na drugom kraiu zemli." Posted December 29. Video, 8:19. https://www.youtube.com/watch?v=y5IdJjKaCgM\&t=26s.

StopXam. N.d.a. “Description." YouTube Channel. Accessed December 31, 2018. https://www.youtube.com/user/stopxamlive/about.

StopXam. N.d.b. Facebook Page. Accessed June 29, 2019. https://www.facebook.com/StopXamTv/. StopXam. N.d.c. VKontakte Page. Accessed June 29, 2019. https://vk.com/stopxam.

Suzdaltsev, Jules. 2015. "We Talked to the Russian Vigilante Group Policing Terrible Drivers." VICE, February 6. https://www.vice.com/en_us/article/av4b85/we-talked-to-the-guy-behindstopxam-206.

Traynor, Ivan. 2001. "Kremlin Silences Its Main Media Critic." Guardian, April 4. https://www.theguardian.com/world/2001/apr/04/russia.iantraynor.

TV Rain. N.d.a. "About Us." Facebook. Accessed November 6, 2018. https://www.facebook.com/ $\mathrm{pg} /$ tvrain/about/?ref=page_internal.

TV Rain. N.d.b. "Bezvozmezdnoe bezvozvratnoe finansirovanie." Accessed October 18, 2019. https://tvrain.ru/donate/.

Vesti. 2012. “Kadyrov uvolil Mingaeva s dolzhnosti zamestitelia polpreda Chechni." May 5. http:// www.vesti.ru/doc.html?id=788040.

Vesti. 2015. “MVD Karelii schitaet aktivistov 'StopXama' khuliganami." October 30. http://www. vesti.ru/doc.html?id=2681419.

Vesti. 2017. "StopXam': 'Stop kharam' ne imeet k nam otnosheniia." March 2. http://www.vesti.ru/ doc.html?id=2861752. 
VGTRK. N.d. "Iz istorii VGTRK." Accessed December 31, 2018. https://vgtrk.com/\#page/221.

Volkov, Denis, and Stepan Goncharov. 2019. “Rossiiskii media-landshaft 2019: Televidenie, pressa, internet i sotsial'nye seti." Levada-Center, August 1. https://www.levada.ru/2019/08/01/ rossijskij-media-landshaft-2019/.

\section{FEATURED INTERVIEWS}

1. Former StopXam participant in Moldova. In-person interview, May 2017

2. Mal Estacionado founders in Peru. Online interview, June 2019

\section{APPENDIX. PROTOCOL FOR DATA COLLECTION, CODING, AND REPORT PRODUCTION}

According to the selected method, initial questions are raised during the protocol stage, which consists of "a list of questions, items, categories, or variables that guide data collection from documents" and tend to be "fairly short, often having a dozen or fewer categories" (Altheide and Schneider 2013:44). I formulated several questions: How are StopXam vigilantes represented in the news? How are the targets represented in the news? How are police forces represented in the news? Who is given the voice in the reports?

In addition to these questions, the following initial categories began to take shape and informed the protocol:

1. Broadcaster

2. Date of the report

3. Headline

4. Frequency of reporting by number of news pieces per broadcaster

5. Location of the event

6. Framing of participants

a) Activists/volunteers/hooligans

b) Doing the right thing

c) Not doing the right thing

d) Motivation

7. Framing of targets

a) General background markers such as: male/female/Slavic/non-Slavic/ rich/famous/poor etc.

b) Guilty

c) Innocent

d) Consequences of retaliation

8. Framing of state bodies: (dys)functional?

9. Nature of retaliation

10. Voice given to: participants, targets, police, state representatives, other?

11. Images and other multimedia (videos, links) accompanying the report: provided by participants?

12. Miscellaneous codes

13. Summary of the initial observations 


\section{CODING}

Altheide and Schneider are cautious about coding and using specialized computer software when it comes to qualitative data analysis, as these programs "cannot deal with meaning, but deal with only common words" (2013:70). The current research is mindful of these issues and relied on coding software-but not out of a desire to find repetitive wording in reports. On the contrary, the software helps to go beyond and apply the three steps of coding: open coding, axial coding, and selective coding. As Starks and Brown Trinidad put it: "The objective of a discourse analysis is to understand what people are doing with their language in a given situation. Thus, the coding phase for a discourse analysis entails identifying themes and roles as signified through language use" (2007:1376). In this regard, the coding phase helped identify themes and nuances in the analyzed reports, while a thorough contextual analysis is supported by a compendium of markers such as tone of the reports as well as featured voices and portrayed parties.

\section{DATA ANALYSIS}

Altheide and Schneider describe this phase as one that "consists of extensive reading, sorting, and searching through your materials; comparing within categories, coding, and adding key words and concepts; and then writing minisummaries of categories" (2013:71). Indeed, the data analysis phase involved a thorough analysis of every document, which allowed identification of certain recurring themes and approaches to framing and portrayal of actors involved: participants, targets, police, etc.

\section{REPORT}

This step involved summarizing each of the categories in a paragraph, using illustrative materials where appropriate, including descriptions and quotations. The article elaborates on general observations concerning StopXam's portrayal within and across selected broadcasters and specific themes (supported by direct quotes from the reports). The report section features a year-by-year coverage of media analysis. The discussion section provides an account of observations made within and across selected media platforms.

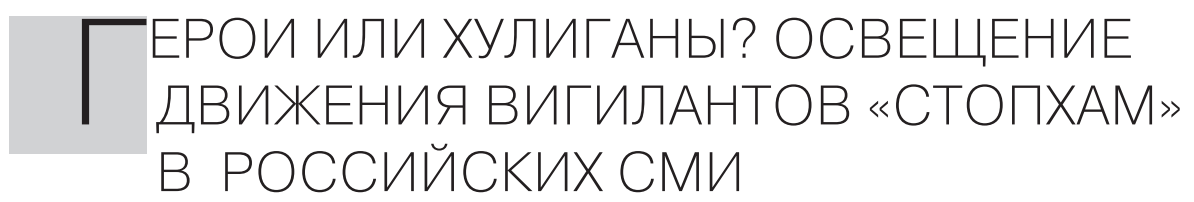

\section{Рашид Габдулхаков}

Рашид Габдулхаков, Факультет медиа и коммуникаций, университет Эразма в Poтmердаме. Адрес для переписки: Erasmus University Rotterdam, Postbus 1738, 3000 DR Rotterdam, Netherlands.gabdulhakov@eshcc.eur.nl. 
Работа выполнена при поддержке проекта Нидерландской организации научных исследований (NWO) № 276-45-004.

На закате деятельности прокремлевского молодежного движения «Наши» его бывшие комиссары при поддержке государства создали несколько вигилантских формирований, борющихся с нарушениями закона и социальных норм. Одной из таких групп является движение «СтопХам», специализирующееся на борьбе с нарушениями правил парковки и дорожного движения. Участники движения «СтопХам» вступают в противостояние с водителями, размещая на лобовых стеклах их автомобилей наклейки с надписью «Мне плевать на всех, паркуюсь где хочу». Возмездие часто сопровождается словесными перепалками и драками; процесс фиксируется на видео, редактируется и публикуется на канале движения в сети YouTube, набирая миллионы просмотров. В то время как социальные медиа сделали данную практику возможной, традиционные СМИ по-прежнему играют важную роль в придании смысла явлению вигилантизма и в формировании дискурса о вигилантах, их жертвах, полиции и прочих акторах. Существующие исследования по цифровому вигилантизму сфокусированы в основном на цифровых медиа, поэтому данная статья призвана восполнить этот пробел посредством качественного анализа новостного освещения движения «СтопХам». Анализ выявил интригующие особенности, связанные с ролью традиционных СМИ в установке дискурса в эпоху цифровых технологий.

Ключевые слова: «СтопХам»; цифровой вигилантизм; гражданское правосудие; Россия; традиционные СМИ; качественный контент-анализ; фрейминг 